\title{
Annual Report on the External Quality Assessment Scheme for Blood Blank Tests in Korea (2014)
}

Young Ae Lim ${ }^{1}$, Jin Sook $\mathrm{Oh}^{1}$, Seog Woon Kwon ${ }^{2}$, Kye Chul Kwon ${ }^{3}$, Shin Young Kim ${ }^{4}$, Kyung Un Park ${ }^{5}$, Hyun Jun Park ${ }^{2}$, Woon Heung Song ${ }^{6}$, Duck Cho ${ }^{7}$, Tae Hyoun $\mathrm{Um}^{8}$, Mi Kyoung Lee, and Sang Moo Han ${ }^{10}$, as Blood Bank Subcommittee, The Korean Association of External Quality Assessment Service ${ }^{1}$ Department of Laboratory Medicine, Ajou University School of Medicine, Suwon; ${ }^{2}$ Department of Laboratory Medicine, Asan Medical Center, Ulsan University School of Medicine, Seoul; ${ }^{3}$ Department of Laboratory Medicine, Chungnam University

School of Medicine, Daejeon; ${ }^{4}$ Department of Laboratory Medicine, Severance Hospital, Yonsei University School of Medicine, Seoul; ${ }^{5}$ Department of Laboratory Medicine, Seoul National University Bundang Hospital, Seongnam; ${ }^{2}$ Department of Biomedical Laboratory Science, Shinhan University, Uijeongbu; Department of Laboratory Medicine, Samsung Medical Center, Sungkyunkwan University School of Medicine, Seoul. ${ }^{8}$ Department of Laboratory Medicine, Ilsan Paik Hospital, Inje University, Goyang; ${ }^{B}$ Blood Laboratory Center Central, Korean Red Cross, Seoul; ${ }^{10}$ Gyeonggi Red Cross Blood Center Central, Korean Red Cross, Suwon, Korea

Corresponding author: Young Ae Lim Department of Laboratory Medicine, Ajou University School of Medicine, 164 World cup-ro, Yeongtong-gu, Suwon 443-380, Korea

Tel:+82-31-219-5786

Fax: +82-31-219-5778

E-mail: limyoung@ajou.ac.kr

pISSN: 2384-2458

elSSN: 2288-7261
We report here the results of surveys on external quality assessment (EQA) of blood bank tests in Korea carried out in 2014. The proficiency testing specimens were prepared at Ajou University Hospital and the response rates for the 1st and 2nd trials were 94.3\% (537/549) and $96.0 \%$ (545/554), respectively. No answers were considered incorrect, and the average accuracy rates of six different test items on the regular survey were as follows: ABO grouping, $98.5 \%$ to $100.0 \%$; $\mathrm{RhD}$ typing, $98.1 \%$ to $99.4 \%$; crossmatching, $91.2 \%$ to $99.6 \%$; direct antiglobulin test (DAT) using a polyspecific reagent, $96.7 \%$ to $98.4 \%$; DAT using an immunoglobulin-G monospecific reagent, $93.8 \%$ to $98.7 \%$; DAT using a C3d monospecific reagent, $89.5 \%$ to $98.7 \%$; unexpected antibody screening test, $96.2 \%$ to $100.0 \%$; and antibody identification test, $69.8 \%$ to $100.0 \%$. Test items for the pilot survey were reactivities to anti-Al and anti-H, Rh subgrouping, and $\mathrm{ABO}$ antibody titration. Except for the result of the antibody identification test for specimens with multiple antibodies, we obtained excellent survey results for the EQA of blood bank tests carried out in 2014. In addition, the number of participating institutes was higher in 2014 than in 2013. The EQA of blood bank tests in 2014 should be helpful for improving the quality of the participating laboratories.

(J Lab Med Qual Assur 2015;37:47-55)

Key Words: Blood banks, Laboratory proficiency testing 


\section{Journal of LABORATORY MEDICINE and QUALITY ASSURANCE}

\section{Young Ae Lim et al • Annual Report on EQA in Blood Banks}

\section{서론}

혈액은행검사는 수혈 전에 시행하는 $\mathrm{ABO}$ 및 $\mathrm{RhD}$ 혈액형 검사, 비예기항체 선별 및 동정검사, 교차시험이 포함되어 있 다. 이들 검사의 정확성은 환자의 생명과도 직결되는 매우 중 요한 요소이다. 대부분 혈액은행에서 실시하고 있는 검사의 원 리는 적혈구와 혈장 혹은 혈청을 이용한 면역혈구 응집법 검사 이다. 그러나 이러한 검사들의 내부정도관리물질들은 널리 상 품화되어 있지도 않을뿐더러 상품화되어 있는 물질은 고가이 기 때문에 일반 검사실에서는 이들을 구입하여 사용하기보다 는 대부분 자가제조물질을 사용하고 있는 실정이다. 이러한 이 유로 혈액은행검사의 외부정도관리 참여는 검사의 신뢰도를 평가할 수 있는 매우 중요한 과정이라고 할 수 있다.

2014년 혈액은행 신빙도조사에는 2013년까지 신빙도조사 에 참여하였던 기관과[1] 신규 가입기관을 포함하여 참여대상 이 모두 554 기관으로 증가하였다. 이 기관들의 종사자들을 대 상으로 교육을 강조하기 위하여 혈액은행 업무에 필요한 실기 와 강의 워크숍을 총 2 회 개최하였다.

이에 저자들은 2014년에 혈액은행분과에서 실시한 $\mathrm{ABO}$ 혈 액형검사, $\mathrm{RhD}$ 혈액형검사, 교차시험검사, 직접항글로불린검 사, 비예기항체 선별검사 및 항체동정검사 등 총 6 가지 항목과 추가로 실시한 세 가지 종류의 시범항목에 대한 신빙도를 조사 하였고, 기관별 검사방법에 대한 결과와 실시하였던 워크숍 개 최 사업내용을 보고하고자 한다.

\section{재료 및 방법}

\section{1. 참여기관}

2014년도 혈액은행 신빙도조사 대상기관은 2013년까지 신 빙도조사에 참여하였던 기관과 신규 가입기관을 대상으로 하 였다. 2014년 5월과 11월 총 2차에 걸쳐 신빙도조사를 실시하 였으며, 1 차 549 기관, 2 차 554 기관에 검체를 발송하였다.

\section{2. 조사항목}

조사항목은 예년과 마찬가지로 $\mathrm{ABO}$ 혈액형검사, $\mathrm{RhD}$ 혈액 형검사, 교차시험검사, 직접항글로불린검사, 비예기항체 선별 검사 및 동정검사 등 6 가지 항목에 대한 신빙도조사를 실시하 였다[1-5]. 시범항목으로 1차 때는 적혈구 $\mathrm{A} 1, \mathrm{H}$ 항원검사 이 외에도 Rh subgrouping검사를 신규로 추가하였고, 2 차 때는 $\mathrm{ABO}$ 항체 역가검사를 시범항목으로 시행하였다.

\section{1) $\mathrm{ABO}$ 혈액형검사}

$\mathrm{ABO}$ 혈액형검사는 $\mathrm{A}$ 형, $\mathrm{B}$ 형, $\mathrm{O}$ 형, $\mathrm{AB}$ 형 중 무작위로 검
체를 선별하여 혈구형검사와 혈청형검사가 가능하도록 매회 3 개의 $\mathrm{ABO}$ 혈구법과 3 개의 $\mathrm{ABO}$ 혈청법 검사용 검체를 제조 하였다.

\section{2) $\mathrm{RhD}$ 혈액형검사}

$\mathrm{RhD}$ 혈액형검사는 $\mathrm{ABO}$ 혈액형검사에 사용된 혈구를 이용 하여 검사하도록 하였다.

\section{3) 교차시험검사}

교차시험검사는 매회 3종류의 검체를 이용하여 교차시험을 실시하게 하였는데 검체별로 실온식염수법, $37^{\circ} \mathrm{C}$ 알부민법, 항글로불린법 단계의 반응을 달리하여 3 단계를 모두 점검할 수 있도록 검체를 제조하여 발송하였다.

\section{4) 직접항글로불린검사}

직접항글로불린검사는 1 차와 2 차로 음성 결과와 양성 결과 를 나타내는 두 가지 유형의 검체를 모두 포함하도록 하여 발 송하였다.

\section{5) 비예기항체 선별검사 및 동정검사}

비예기항체 선별검사 및 동정검사는 항체선별검사만 실시하 는 기관과 동정검사까지 실시하는 기관을 분류하여 검체가 발 송되었다. 즉 비예기항체 선별검사만 실시하는 기관에는 2 종 류의 검체가 2 차에 걸쳐 운송되었으며, 비예기항체 동정검사 까지 실시한 기관은 3 종류의 검체가 2 차에 걸쳐 운송되어 총 4 검체에서 6검체까지 포함하였다. 특히 2014년 2차 사업부터는 가격이 비싼 동정검사용 검체의 낭비를 막기 위하여 동정검사 를 신청하였으나 결과를 입력하지 않았던 50 여 개의 기관에게 동정검사 신청 철회 요청과 지속 신청 시의 결과 미입력은 오 답 처리한다는 안내문을 보내어 신청을 지속한다는 답변을 준 기관에만 추가로 검체를 발송하였다. 비예기항체 동정용 양성 검체로 1 차는 anti-D와 anti- $\mathrm{E}$, anti-S, 2차는 anti-D, anti-C와 $\mathrm{e}$ 의 혼합, anti-Fy 항혈청 시약을 각각 희석하여 발송하였다.

\section{6) 시범항목}

1 차 때는 적혈구 $\mathrm{A} 1, \mathrm{H}$ 항원검사 및 $\mathrm{Rh}$ subgrouping 검사 항목인 C,c,E,e 항원검사, 2차 때는 $\mathrm{ABO} \mathrm{Ab}$ 역가검사를 실시 하였다.

\section{7) 워크숍 개최}

혈액은행 실기 워크숍은 혈액은행분과 단독으로 주관하여 총 2 회의 워크숍을 개최하고자 하였다. 워크숍에 대한 공지는 개최 전에 홈페이지의 게시판과 문자수신 등을 이용하였다. 


\section{3. 검체의 제조 및 우송}

모든 정도관리 검체는 기존의 방법처럼 [1-5] 아주대학교병 원 혈액은행에서 제조하였는데 혈구 검체는 대한적십자사에 서 공급받은 CPDA (citrate phosphate dextrose adenine)-1 혈액 백에서 분리된 농축적혈구를 생리식염수로 $10 \%$ 로 희석 하였으며, 혈장 검체는 신선동결혈장을 냉동 보관한 후 무균봉 합기로 연결하여 혼합한 다음 분주하였다.

직접항글로불린검사용 검체는 인간유래 다클론성 anti-D (DiaMed GmbH, Cressier, Switzerland)를 사용하여 인위 적으로 감작시킨 혈구를 사용하였고, 교차시험용 검체는 동 일 Biorad사의 anti-D (DiaMed GmbH)를 폐기혈청에 첨가 하여 반응 역가를 결정하여 사용하였다. 또한 항체 선별 및 동 정검사용 검체를 위하여 상품화된 인간유래 다클론성 항체인 Biorad사(DiaMed GmbH)의 anti-D, anti-S, anti Fy 와 인 간유래 하이브리도마 단클론성, IgM형인 Diagast사(Loos, France) anti- $\mathrm{E}$, anti-C, anti-e를 폐기혈청에 첨가한 후 항글 로불린 단계에서의 혈구 응집 정도를 조절하여 제조하였다.

자가제조된 모든 검체는 검사자 2 인이 각각 검사하여 결과 및 응집 정도를 확인하였다. 검체의 파손을 줄이기 위하여 에 어 비닐을 이용하여 검체를 포장하였고, 참여기관 도착 전까지 의 검체의 실온 노출기간을 최소화하기 위하여 금요일에 제조 및 포장된 검체를 냉장 보관하였다가 월요일 오전에 일괄 익일

Table 1. Number (responder \%) of participants for each test item of the survey in the first and second trials

\begin{tabular}{llll}
\hline \multicolumn{1}{c}{ Survey item } & \multicolumn{1}{c}{ 2014-1 } & \multicolumn{1}{c}{ 2014-2 } & \multicolumn{1}{c}{ Mean } \\
\hline ABO grouping & $537(100.0)$ & $545(100.0)$ & $541(100.0)$ \\
RhD typing & $534(99.4)$ & $541(99.3)$ & $538(99.4)$ \\
Crossmatching & $479(89.2)$ & $486(89.2)$ & $483(89.2)$ \\
Direct antiglobulin test & $373(69.5)$ & $379(69.5)$ & $376(69.5)$ \\
Ab screening test & $283(52.7)$ & $286(52.5)$ & $285(52.6)$ \\
Ab identification test & $125(23.3)$ & $126(23.1)$ & $126(23.2)$ \\
\hline
\end{tabular}

Abbreviation: $\mathrm{Ab}$, antibody.
배송하였다.

\section{결과}

\section{1. 신빙도조사 참여기관 수 및 회신율}

2014년 혈액은행검사 신빙도조사의 참여기관 및 회신율은 Table 1에 기술하였는데, 6 가지의 신빙도조사항목 중 한 종목 의 한 가지 검체라도 결과를 입력한 기관은 모두 참여기관으로 포함시켰다. 검체가 발송된 기관 수는 1차(2차)가 549 (554) 기관으로 평균 552 기관이었으며, 회신 기관 수는 1 차(2차)가 537 기관(545기관)인 평균 541 기관으로 회신율은 1 차(2차)가 97.8\% (98.4\%)로 평균 98.1\%였다.

조사항목별로 평균 회신 기관 수를 살펴보면 $\mathrm{ABO}$ 혈액형 검사를 시행하는 541 기관을 $100 \%$ 로 간주할 경우 $\mathrm{RhD}$ 검사는 538 기관(99.4\%), 교차시험은 483기관(89.2\%), 직접항글로불 린검사는 376 기관(69.5\%), 항체선별검사는 285 기관(52.6\%), 그리고 항체동정검사는 126 기관(23.2\%)이 검사 시행 후 결과 를 회신하였다(Table 1). 이와 같은 회신기관의 비율은 항체동 정검사의 회신율이 $3 \%$ 감소한 것 이외에는 각 종목은 예년과 유사하였다. 정답률 산정 시는 검사법이 다양하여 참여기관의 수를 정확히 산정하기 곤란한 교차시험을 제외하고는 미입력 기관은 오답으로 처리하였다.

\section{2. 조사항목}

\section{1) $\mathrm{ABO}$ 혈액형검사}

$\mathrm{ABO}$ 혈액형검사는 2 차에 걸쳐 총 6 개의 검체로 실시하였 고, 1차는 98.5-100.0\%, 2차는 99.3-99.6\%의 정답률을 나타 내는데, 한 개의 검체라도 입력을 하지 않아 오답으로 간주된 기관은 1 회차에 9 기관, 2 회차에 3 기관이었다(Table 2). 1차 (2차)의 혈구형검사법은 슬라이드법이 $61.6 \%$ (49.5\%)로 가 장 많이 사용하는 방법으로 나타났으며, 그 뒤를 이어 시험관 법이 $36.8 \%$ (49.3\%)를 차지하였다. 1 차(2차)의 혈청형검사 법은 시험관법이 $81.9 \%$ (83.4\%)로 가장 많이 사용하는 방법

Table 2. Performance results of $\mathrm{ABO}$ grouping and $\mathrm{RhD}$ typing

\begin{tabular}{|c|c|c|c|c|c|c|}
\hline Survey no. & Specimen & Participants & Correct answer (\%) & Specimen & Participants & Correct answer (\%) \\
\hline \multirow[t]{3}{*}{ 2014-1 } & Group O & $537\left(1^{\star}\right)$ & $536(99.8)$ & $\mathrm{RhD}(+)$ & $537\left(3^{\star}\right)$ & $533(99.2)$ \\
\hline & Group A & $537\left(8^{\star}\right)$ & $529(98.5)$ & $\mathrm{RhD}(+)$ & $537\left(3^{\star}\right)$ & $534(99.4)$ \\
\hline & Group B & 537 & $537(100.0)$ & $\mathrm{RhD}(-)$ & $537\left(9^{\star}\right)$ & $527(98.1)$ \\
\hline \multirow[t]{3}{*}{ 2014-2 } & Group AB & $545\left(2^{\star}\right)$ & $541(99.3)$ & $\mathrm{RhD}(+)$ & $545\left(5^{\star}\right)$ & $540(99.1)$ \\
\hline & Group B & 545 & $543(99.6)$ & $\mathrm{RhD}(+)$ & $545\left(4^{\star}\right)$ & $540(99.1)$ \\
\hline & Group A & $545\left(1^{\star}\right)$ & $541(99.3)$ & $\mathrm{RhD}(-)$ & $545\left(7^{\star}\right)$ & $537(98.5)$ \\
\hline
\end{tabular}

${ }^{\star}$ No. of non-responders. 
으로 나타났으며, 그 뒤를 이어 슬라이드법이 $12.1 \%$ (10.6\%) 이었으며, 마이크로웰 플레이트법은 $0.6 \%(0.6 \%)$ 를 차지하 였다. 특징적인 소견은 1 차에 비하여 2 차 시에 슬라이법이 감 소한 만큼 시험관법이 증가하였는데, 특히 혈구형검사에서 두 드러졌다(Table 3). ABO 혈액형검사의 혈청형검사를 위해서 사용하는 적혈구는 1차와 2차는 회신기관의 $62.2 \%$ 와 $63.9 \%$ 에서 자가제조법으로 제조하여 사용하였다고 보고하였다.

\section{2) $\mathrm{RhD}$ 혈액형검사}

$\mathrm{RhD}$ 혈액형검사결과 1차는 98.1-99.4\%, 2차는 98.5$99.1 \%$ 의 정답률을 나타내었다(Table 2). 1차(2차)의 검사법 은 1차에서는 2013년과 유사하게 슬라이드법이 $55.5 \%$ 를 차 지하여 가장 많이 사용하는 방법으로 나타났으나 2차 결과에 서는 시험관법이 $51.2 \%$ 로 슬라이드법 $45.3 \%$ 보다 높은 것으 로 나타났다. 그 뒤 원주응집법이 1.3 (0.9\%)를 차지하였다 (Table 3).

\section{3) 교차시험검사}

교차시험검사는 2 차에 걸쳐 총 6 개의 검체가 사용되었으며,
검체에 따라 1차는 91.4-99.6\%, 2차는 91.2-99.2\%에서 정답 률을 보였다. 적합 및 부적합 검체에 대하여 각 단계별 정답률 을 분석한 결과, 적합 검체는 $99.2-99.6 \%$ 이고, 부적합 검체 가 91.2-97.5\%로 부적합 검체에서 오답률이 더 높았다(Table 4). 검사법은 시험관법이 1차(2차)가 각각 $82.7 \%$ (80.6\%)로 가장 많이 사용하는 방법으로 나타났으며, 원주응집법 $16.1 \%$ (18.1\%), 마이크로웰 플레이트법 모두 $0.2 \%$ (0.4\%)를 차지 하였으며, 응답을 하지 않은 기관도 $1.0 \%(1.0 \%)$ 를 차지하였다.

\section{4) 직접항글로불린검사}

직접항글로불린검사는 2 차에 걸쳐 총 4 개의 검체가 사용 되었는데, 다특이성 항글로불린법의 1차(2차)의 정답률은 양 성 검체 $96.7 \%$ (97.0\%)였으며, 음성 검체는 98.4\% (98.2\%) 로 양성 검체에 대한 오답률이 더 높은 것으로 분석되어 예년 과 동일한 양상을 보였다. 1차(2차)의 $\operatorname{IgG}$ 단특이성 항글로 불린을 사용한 경우 음성이었던 검체에 대한 정답률은 $97.4 \%$ (98.7\%)로 양성이었던 검체에 대한 정답률 $93.8 \%$ (97.4\%)에 비하여 높았다. 마찬가지로 C3d 단특이성 항글로불린을 사용 한 경우도 음성이었던 검체에 대한 정답률은 $98.6 \%$ (98.7\%)

Table 3. Number (\%) of participants of $\mathrm{ABO}$ and $\mathrm{RhD}$ typing according to technique

\begin{tabular}{|c|c|c|c|c|c|c|}
\hline \multirow{3}{*}{ Technique } & \multicolumn{4}{|c|}{ ABO typing } & \multicolumn{2}{|c|}{ RhD typing } \\
\hline & \multicolumn{2}{|c|}{ 2014-1 } & \multicolumn{2}{|c|}{ 2014-2 } & \multirow{2}{*}{ 2014-1 (\%) } & \multirow{2}{*}{$2014-2(\%)$} \\
\hline & Cell (\%) & Serum (\%) & Cell (\%) & Serum (\%) & & \\
\hline Slide & $331(61.6)$ & $65(12.1)$ & $270(49.5)$ & $58(10.6)$ & $298(55.5)$ & $247(45.3)$ \\
\hline Tube & $197(36.8)$ & $440(81.9)$ & $269(49.3)$ & $455(83.4)$ & $218(40.6)$ & $279(51.2)$ \\
\hline Microwell & $4(0.7)$ & $3(0.6)$ & $3(0.6)$ & $3(0.6)$ & $7(1.3)$ & $3(0.6)$ \\
\hline Column agglutination technology & $4(0.7)$ & $5(0.9)$ & $2(0.4)$ & $2(0.4)$ & $6(1.1)$ & $5(0.9)$ \\
\hline No answer & $1(0.2)$ & $24(4.5)$ & $1(0.2)$ & $27(5.0)$ & $8(1.5)$ & $11(2.0)$ \\
\hline Total & $537(100.0)$ & $537(100.0)$ & $545(100.0)$ & $545(100.0)$ & $537(100.0)$ & $545(100.0)$ \\
\hline
\end{tabular}

Table 4. Performance results for crossmatching

\begin{tabular}{|c|c|c|c|c|c|c|}
\hline \multirow{2}{*}{$\begin{array}{c}\text { Survey } \\
\text { no. }\end{array}$} & \multirow{2}{*}{$\begin{array}{c}\text { Specimen } \\
(\mathrm{S}, \mathrm{A}, \mathrm{AHG})\end{array}$} & \multirow{2}{*}{ Participants } & \multirow{2}{*}{$\begin{array}{l}\text { Correct } \\
\text { decision }\end{array}$} & \multicolumn{3}{|c|}{ Participant consensus (\%) } \\
\hline & & & & Saline & $37^{\circ} \mathrm{C}$ albumin & AHG \\
\hline \multirow[t]{2}{*}{$2014-1$} & Compatible (-,-,-) & 479 & $477(99.6)$ & $397(99.7)$ & $390(99.0)$ & $465(99.6)$ \\
\hline & Incompatible $(-,+,+)$ & 479 & $438(91.4)$ & $388(98.2)$ & $386(98.5)$ & $427(92.2)$ \\
\hline \multirow[t]{2}{*}{$2014-2$} & Compatible (-,-,-) & 486 & $482(99.2)$ & $391(100.0)$ & $386(99.5)$ & $469(99.4)$ \\
\hline & Incompatible $(-/+,+,+)$ & 486 & $469(96.5)$ & $389(99.7)$ & $367(94.6)$ & $456(97.0)$ \\
\hline
\end{tabular}

Abbreviations: S, saline or low ionic strength saline at room temperature; $\mathrm{A}, 37^{\circ} \mathrm{C}$ incubations with addition of albumin or not; $\mathrm{AHG}$, antihuman globulin. 


\section{Young Ae Lim et al • Annual Report on EQA in Blood Banks}

로 양성이었던 검체에 대한 정답률 $94.4 \%$ (89.5\%)에 비하 여 높았다(Table 5). 검사법은 시험관법이 1차와 2차가 모두 동일하게 $50.5 \%$ 씩으로 가장 많이 사용하였으며 원주응집법 $48.9 \%$ 씩, 마이크로웰 플레이트법 모두 $0.4 \%$ 씩 각각 차지하 였다.

\section{5) 비예기항체 선별 및 동정검사}

항체선별검사의 정답은 1 차와 2 차 모두 양성이었으며 검 체에 따라 96.2-100.0\%의 정답률을 나타내었고, 항체동정검 사의 정답률은 anti- $\mathrm{D}$ 는 1차 $100.0 \%$ (2차 $99.2 \%$ ), anti- $\mathrm{E}$ $100.0 \%$, anti-S 95.2\%이며 anti-Fy 는 93.7\%의 정답률을 보 였다. 2차 사업 시는 anti-C와 anti-e 혼합혈청을 발송하였는 데 정답률은 $69.8 \%$ 였으며, 각각의 항체에 대해서는 $76.9 \%$, $85.7 \%$ 의 정답률을 보였고, anti-C만 검출한 기관은 $5.6 \%$, anti-e만 검출한 기관은 $15.9 \%$, 이 이외의 항체라고 보고한 기관은 $6.3 \%$ 이며, 이 이외의 항체와 anti-C가 혼재되어 있다 고 보고한 기관은 $1.6 \%$ 였다(Table 6 ). 미입력기관도 anti-S 4기관, anti-C, anti-e 각각 1기관, anti-Fy ${ }^{\mathrm{b}}$ 6기관 모두 오답 으로 처리하였다(Table 6).

1차(2차)의 항체선별검사법은 원주응집법이 $90.46 \%$ (91.6\%)
로 가장 많이 사용하는 방법으로 해마다 사용기관이 증가하 고 있으며, 시험관법 $7.1 \%$ (5.9\%), 마이크로웰 플레이트법이 모두 $1.8 \%(2.5 \%)$ 를 차지하였다. 1차(2차)의 항체동정검사 법도 항체선별검사법과 유사한 양상을 보였는데 원주응집법 $96.8 \%$ (97.6\%)로 가장 많이 사용하는 방법으로 나타났으며, 시험관법은 모두 $1.6 \%$ 로 감소하였고, 마이크로웰 플레이트법 모두 $0.8 \%$ 를 차지하였다(Table 7). 적혈구를 자가제조법으로 제조하여 검사에 이용하고 있다고 응답한 기관의 비율은 비예 기항체선별검사는 1 차(2차) $2.9 \%$ (1.5\%), 동정검사는 $2.2 \%$ $(0 \%)$ 를 차지하였다.

\section{6) 시범항목}

적혈구 $\mathrm{A} 1, \mathrm{H}$ 항원은 1 차 때만 실시하였는데 anti-A1과 anti-H 시약에 대하여 각각 53 개 기관과 49 개의 기관이 응답 하여 $\mathrm{ABO}$ groping 참여기관인 537 기관의 각각 $9.7 \%$ 와 $9.1 \%$ 가 참여하였다. 이는 2012년도 62-67기관, 2013년의 58-60기 관에 비하여 참여기관의 수는 감소하였다. 정답은 전년도와 마 찬가지로 $\mathrm{A} 1$ 검체의 경우 $\mathrm{A} 1$ 항원 검사는 $2+$ 이상, $\mathrm{H}$ 항원검 사는 $1+$ 이하, $\mathrm{O}$ 검체의 경우 $\mathrm{A} 1$ 항원 검사는 음성, $\mathrm{H}$ 항원 검사는 $2+$ 이상으로 간주하였다. Anti-A1에 대한 반응은 $\mathrm{A} 1$

Table 5. Performance results of a direct antiglobulin test

\begin{tabular}{|c|c|c|c|c|c|c|c|}
\hline \multirow{3}{*}{$\begin{array}{c}\text { Survey } \\
\text { no. }\end{array}$} & \multirow{3}{*}{$\begin{array}{c}\text { Result } \\
(\mathrm{P}, \mathrm{G}, \mathrm{C})\end{array}$} & \multirow{2}{*}{\multicolumn{2}{|c|}{ Polyspecific AHG }} & \multicolumn{4}{|c|}{ Monospecific AHG } \\
\hline & & & & \multicolumn{2}{|c|}{ Anti-IgG } & \multicolumn{2}{|c|}{ Anti-C3d } \\
\hline & & No.* & $\%$ & No.* & $\%$ & No.* & $\%$ \\
\hline 2014-1 & $(-,-,-)$ & $361 / 367$ & 98.4 & $75 / 77$ & 97.4 & $69 / 70$ & 98.6 \\
\hline $2014-2$ & $(+,+,-)$ & $359 / 370$ & 97.0 & $76 / 78$ & 97.4 & $68 / 76$ & 89.5 \\
\hline
\end{tabular}

Abbreviations: +, positive; -, negative; AHG, anti-human immunoglobulin; C, anti-C3d; G, anti-immunoglobulin G; P, polyspecific antihuman globulin.

*Institute's number with correct answer/participants' number.

Table 6. Performance results of unexpected antibody screening and identification tests

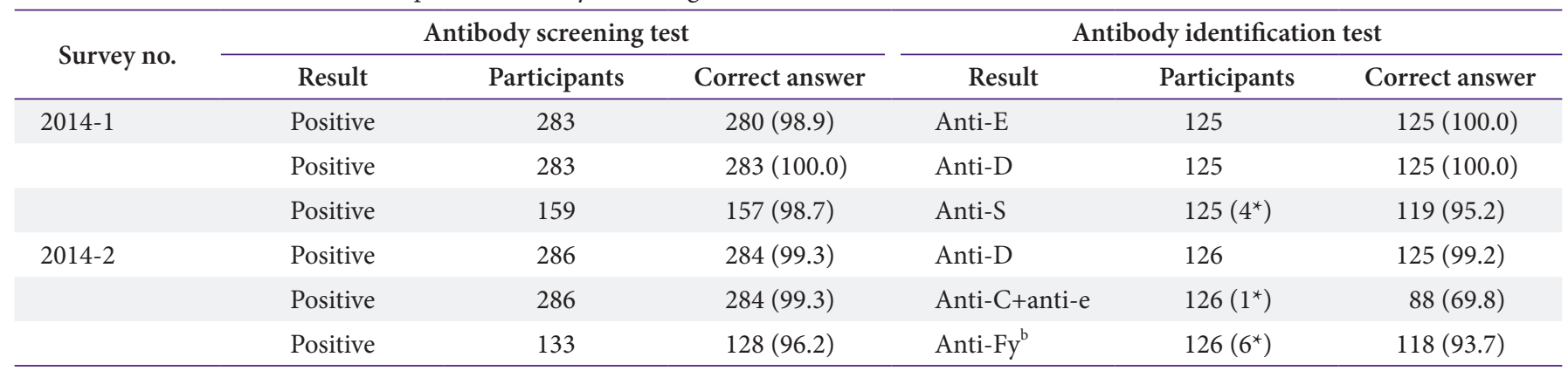

${ }^{\star}$ Number of non-responders. 


\section{Journal of LABORATORY MEDICINE and QUALITY ASSURANCE}

\section{Young Ae Lim et al • Annual Report on EQA in Blood Banks}

Table 7. Number (\%) of participants of unexpected antibody screening and identification tests according to technique

\begin{tabular}{lccccc}
\hline \multirow{2}{*}{ Technique } & \multicolumn{2}{c}{ Antibody screening } & & \multicolumn{2}{c}{ Antibody identification } \\
\cline { 2 - 3 } \cline { 5 - 6 } & $2014-1(\%)$ & $2014-2(\%)$ & & 2014-1 (\%) & 2014-2 (\%) \\
\hline Column agglutination technology & $256(90.4)$ & $262(91.6)$ & & $121(96.8)$ & $123(97.6)$ \\
Tube & $20(7.1)$ & $17(5.9)$ & & $2(1.6)$ & $2(1.6)$ \\
Microwell & $5(1.8)$ & $7(2.5)$ & & $1(0.8)$ & $1(0.8)$ \\
No answer & $2(0.7)$ & 0 & $1(0.8)$ & 0 \\
Total & $283(100.0)$ & $286(100.0)$ & & $125(100.0)$ & $126(100.0)$ \\
\hline
\end{tabular}

Table 8. Results of antigen testing for the presence of $\mathrm{Al}$ and $\mathrm{H}$ antigens

\begin{tabular}{|c|c|c|c|c|}
\hline \multirow{3}{*}{ Result } & \multicolumn{4}{|c|}{$\mathrm{ABO}$} \\
\hline & \multicolumn{2}{|c|}{$\mathrm{O}(\mathrm{R} 1)$} & \multicolumn{2}{|c|}{ A1 (R2) } \\
\hline & Anti-A1 & Anti-H & Anti-A1 & Anti-H \\
\hline Negative & $53(100.0)$ & $3(6.1)$ & 0 & $23(47.0)$ \\
\hline Trace-1+ & 0 & $3(6.1)$ & 0 & $20(40.8)$ \\
\hline $2+$ & 0 & $8(16.3)$ & $3(5.7)$ & $6(12.2)$ \\
\hline $3+$ & 0 & $7(14.3)$ & $1(1.9)$ & 0 \\
\hline $4+$ & 0 & $28(57.2)$ & $49(92.4)$ & 0 \\
\hline Total & $53(100.0)$ & $49(100.0)$ & $53(100.0)$ & $49(100.0)$ \\
\hline
\end{tabular}

Values are presented as participants (\%). R1 and R2 are the proficiency testing specimens for $\mathrm{ABO}$ and $\mathrm{RhD}$ typing.
Table 9. Results (\%) of antigen testing for the presence of C, c, E, and e antigens $(n=45)$

\begin{tabular}{lllcl}
\hline \multirow{2}{*}{ Result } & \multicolumn{4}{c}{ Rh subgrouping of R3 } \\
\cline { 2 - 5 } & \multicolumn{1}{c}{$\mathrm{C}$} & \multicolumn{1}{c}{$\mathrm{c}$} & $\mathrm{E}$ & $\mathrm{e}$ \\
\hline Negative & $44(97.8)$ & 0 & $1(2.2)$ & 0 \\
Trace-1+ & 0 & $1(2.2)$ & 0 & $4(8.9)$ \\
$2+$ & $1(2.2)$ & $6(13.3)$ & $5(11.1)$ & $14(31.1)$ \\
$3+$ & 0 & $9(20.0)$ & $12(26.7)$ & $15(33.3)$ \\
$4+$ & 0 & $29(64.4)$ & $26(57.8)$ & $12(26.7)$ \\
No answer & 0 & 0 & $1(2.2)$ & 0 \\
\hline
\end{tabular}

$\mathrm{R} 3$ is the proficiency testing specimen for $\mathrm{ABO}$ and $\mathrm{RhD}$ typing.

Table 10. Number of participants for anti-B antibody titration results in blood group A according to technique

\begin{tabular}{|c|c|c|c|c|c|c|c|c|c|c|c|c|c|}
\hline Techniques & $\mathrm{N}$ & Negative & $1: 1$ & $1: 2$ & $1: 4$ & $1: 8$ & $1: 16$ & $1: 32$ & $1: 64$ & $1: 128$ & $1: 256$ & $1: 512$ & $1: \geq 1,024$ \\
\hline Tube-IS $\left(100.0 \%^{*}\right)$ & 30 & 0 & 0 & 0 & 2 & 11 & 10 & 7 & 0 & 0 & 0 & 0 & 0 \\
\hline Tube-RT $(100.0 \% *)$ & 16 & 0 & 0 & 0 & 0 & 2 & 8 & 6 & 0 & 0 & 0 & 0 & 0 \\
\hline Tube-AHG $(90.0 \% *)$ & 20 & 1 & 1 & 0 & 0 & 5 & 10 & 3 & 0 & 0 & 0 & 0 & 0 \\
\hline CAT-RT & 4 & 0 & 0 & 0 & 1 & 2 & 1 & 0 & 0 & 0 & 0 & 0 & 0 \\
\hline CAT-AHG $\left(89.5 \%{ }^{\star}\right)$ & 19 & 1 & 0 & 1 & 1 & 9 & 7 & 0 & 0 & 0 & 0 & 0 & 0 \\
\hline Dithiothreitol treatment & 10 & 3 & 0 & 3 & 1 & 0 & 2 & 1 & 0 & 0 & 0 & 0 & 0 \\
\hline Other & 0 & 0 & 0 & 0 & 0 & 0 & 0 & 0 & 0 & 0 & 0 & 0 & 0 \\
\hline
\end{tabular}

Bold characters express the allowable range for anti-B Ab titre.

Abbreviations: IS, immediate spin; RT, room temperature incubation; AHG, indirect anti-human globulin test; CAT, column agglutination technology.

${ }^{\star}$ Percentage of participants within allowable range.

검체와 $\mathrm{O}$ 검체에서 모두 $100.0 \%$ 를 보였으나, anti-H의 경우 $\mathrm{A} 1$ 검체와 $\mathrm{O}$ 검체에서 모두 $87.8 \%$ 를 보여 2013년도의 각각 $98.3 \%$ 와 $96.6 \%$ 에 비하여 낮았다(Table 8).

2014년에도 1회차 사업에는 신규로 anti-C, anti-c, anti-E, anti-e 시약의 반응성을 검증하기 위한 혈액형검사용 R3검체 에서 Rh subgrouping검사를 추가로 시행하였다. 신규종목이 라 반응 정도에 상관없이 양성과 음성만을 기준으로 평가하였
는데, 오답률은 C항원 $2.2 \%, \mathrm{E}$ 항원 $2.2 \%$ 였으며, e항원과 c항 원의 경우 양성임에도 불구하고 'trace 혹은 $1+$ '로 보고한 기 관도 각각 $8.9 \%$ 와 $2.2 \%$ 나 되었다(Table 9 ).

$\mathrm{ABO}$ 항체역가검사는 2014년에도 2회차에만 1회 실시되 었는데, 각 방법별 참여기관의 수와 결과는 Table 10 과 같다. 검체의 혈액형은 $\mathrm{A}$ 형으로 anti-A는 모두 음성으로 답하였기 때문에 anti-B만 분석하였고, 각 항체의 허용범위는 예년과 


\section{Journal of LABORATORY MEDICINE and QUALITY ASSURANCE}

\section{Young Ae Lim et al • Annual Report on EQA in Blood Banks}

는 달리 2013년 이후의 'ABT-A antibody titer participant summary from the College of American Pathologists'에 따 라 최빈도역가 \pm 1 배수 혹은 4단계 역가 이내에서 $80 \%$ 이상 의 기관들이 답변을 보인 경우로 정의하였다. 결과 입력기관 이 10 기관 이상인 경우만 분석하였는데, anti-B dithiothreitol (DTT) 처리는 참여기관이 10 기관이었으나 4단계 역가 이내 에서 $80 \%$ 이상의 기관들의 답변이 일치하지 않아 분석하지 않았다.

허용범위에 드는 참여기관 비율은 시험관 즉시 원침법과 실 온배양법은 $100.0 \%$, 시험관 항글로불린법 $90.0 \%$ 그리고 원 주응집 항글로불린법이 $89.5 \%$ 였다. 시험관법은 30 기관 원주 응집법은 19 기관에서 사용하였고, DTT 처리기관은 10 기관이 었다(Table 10).

\section{3. 워크숍 개최}

1차는 ABO 혈액형 실기 워크솝으로 2014년 7월 4일(금) 오 후 1 시부터 5 시까지 아주대학교 의과대학 송재관 학생실습실 에서 $\mathrm{ABO}$ 아형, $\mathrm{D}$ 변이형 검체검사 검출법에 대한 강의와 실 습이 이루어졌으며 총 60 명이 등록하여 참석하였다. 비예기항 검사에 대한 2차 워크숍은 2014년 8월 29일(금) 오후 1시부터 5 시까지 아주대학교 의과대학 송재관 학생실습실에서 교차검 사, 비예기항체 선별과 동정에 대한 강의와 실습이 이루어졌으 며, 총 53명이 등록하여 참석하였다.

\section{고찰}

2014년 혈액은행검사 신빙도조사의 참가기관은 2013년도 520 기관에 비하여 평균 5기관 증가하였는데, 회신율은 $98.1 \%$ 로 2012년 97.1\%, 2013년 95.1\%에 비하여 증가하였다[1,2]. 최근 2 년간 감소된 회신율이 2014년 다시 증가한 이유는 올해 신빙도사업 전에 정도관리사업비를 지불하여 확실하게 참여 의사를 밝힌 기관에게만 검체를 발송하였기 때문으로 여겨졌다.

$\mathrm{ABO}$ 와 $\mathrm{RhD}$ 혈액형 정답률은 예년과 유사하였으나 결과를 입력하지 않아 오답으로 처리된 기관은 오히려 증가하였다. 회 차당 보낸 3개의 검체 중에서 일부만을 입력하지 않은 기관들 이 대부분이므로 정답이 어려워 결과를 입력하지 못하였다기 보다는 결과 입력과정의 사무적 착오 가능성이 높은 것으로 분 석된다. 혈액형검사의 경우 대부분의 검사실에서 결과가 자동 전송되는 자동화분석기가 아닌 수기법을 사용하여 결과 역시 수기도 입력하여야 하므로 환자의 검사결과 입력 시 반드시 2 인이 확인하는 체계를 외부신빙도조사 시 그리고 결과 입력 시 도 적용하여 확인할 필요가 있다고 여겨졌다.
2회차 사업 시는 검체 발송 시 모든 기관에 $\mathrm{ABO}$ 와 $\mathrm{RhD}$ 혈 액형 검사 시 슬라이드법을 가급적 시험관법으로 전환하는 것 을 권장하는 안내문을 발송하였다. 이는 국내 참여기관의 약 $60 \%$ 정도가 혈액형검사 시 슬라이드법을 사용하고 있으나 미 국의 College of American Pathologists의 혈액형 외부신빙도 조사에서는 슬라이드법 선택사항이 없으며, 영국의 경우 1982 년 29\%였던 슬라이드법 사용이 2002년 이미 $1 \%$ 미만으로 감 소하였다는 연구결과와[6] 이를 2014년 추계학술대회 시 발 표한 결과 이에 대한 교육이 필요하다는 참가자들의 의견을 반영한 것이었다. 왜냐하면 검사자와 검체와의 접촉으로 인 한 감염의 위험성을 감소시키고 혈액형검사의 정확도를 향상 시키기 위해서는 혈액형검사 시 슬라이드기법을 지양할 필요 가 있는데, 특히 $\mathrm{ABO}$ 아형의 경우 슬라이드법으로는 검출하 기 곤란하기 때문이다. 이러한 안내문 효과로 1차에 비하여 2 차 시에 $\mathrm{ABO}$ 혈구형검사를 슬라이법으로 시행한 기관의 비 율이 $61.6 \%$ 에서 $49.5 \%$ 로 낮아지고 대신 시험관법이 $36.8 \%$ 에서 $49.3 \%$ 로 증가하였으며, $\mathrm{RhD}$ 혈액형검사의 슬라이법도 $55.5 \%$ 에서 $45.3 \%$ 로 낮아지고 대신 시험관법이 $40.6 \%$ 에서 $51.2 \%$ 로 상당히 증가하였다. 이는 안내문으로도 충분히 교육 효과를 얻을 수 있었던 것으로 보여지고, 슬라이드법 감소를 위하여 향후 지속적으로 안내문을 제공할 필요가 있다고 여겨 졌다.

교차시험의 경우 2013년도와 마찬가지로 실온식염수법에서 는 음성을 보이나 항온 알부민 단계부터 혹은 항글로불린 단계 에서만 양성을 보였던 검체의 양성률은 91.2-91.4\%로 3단계 의 반응이 동일한 다른 검체에 비하여 정답률이 낮았다. 이는 오답을 보인 기관들이 실온식염수법에 비하여 항글로불린 단 계의 교차시험에 대하여 검사법이 미숙하여 정확도가 떨어지 기 때문인 것으로 분석되어 이에 대한 지속적인 교육이 필요할 것으로 판단하였다.

직접항글로불린검사의 경우 예년처럼 $\mathrm{C} 3 \mathrm{~d}$ 단특이성 항글로 불린검사는 음성임에도 불구하고 양성이라고 보고한 기관들 은 다특이성 혹은 $\operatorname{IgG}$ 단특이성 직접항글로불린 검사의 결과 가 양성인 경우 함께 양성으로 보고한 것으로 이들에 대한 바 이어스 영향을 받은 것으로 해석되었다. 따라서 오답기관은 $\mathrm{C} 3 \mathrm{~d}$ 단특이성 항글로불린 시약을 재검토하거나 혹은 이의 검 사방법이나 해석에 대한 재교육이 필요한 것으로 판단되었다. 외부정도관리물질도 비록 구하기는 어렵지만 C3d만 양성인 물질의 사용도 고려하여 참여기관의 숙련도를 좀 더 정확히 판 정할 필요가 있을 것으로 여겨졌다.

비예기항체 선별검사의 경우 1 차와 2 차 모두 양성인 검체를 발송하였는데, 이는 참가기관이 다양한 항체를 동정하는데 도 


\section{Journal of LABORATORY MEDICINE and QUALITY ASSURANCE}

Young Ae Lim et al • Annual Report on EQA in Blood Banks

움을 주기 위해서였다. Anti-D를 제외하고는 희석된 인간유래 다클론항체였던 anti-S와 anti-Fy ${ }^{\mathrm{b}}$ 의 정답률은 IgM 단클론항 체 시약인 anti-E에 비하여 낮았는데, 이는 인간유래 다클론항 체가 IgM 단클론 항체에 비하여 혈구응집이 적고 항글로불린 단계에서만 반응하기 때문인데, 이러한 특성은 오히려 환자 검 체에 가까우므로 향후에도 가능한 인간유래 다클론항체가 계 속 외부정도관리물질로 사용될 필요가 있다고 여겨졌다.

2차 사업 시 시도한 혼합혈청인 anti-C와 anti-e의 정답률 은 $69.8 \%$ 로 매우 낮았다. 아마도 이는 혼합혈청을 처음으로 시도하였기 때문으로 혼합항체 동정에 익숙하지 않은 참가기 관들이 한가지씩만 동정하였을 수도 있으며, 항체 동정혈구 패 널상 e항원 양성인 혈구는 대부분 $\mathrm{C}$ 항원도 양성이기 때문으로 anti-e만 검출한 기관이 $15.9 \%$ 나 되는 것도 그 이유인 것으로 보여졌다. 그러나 $\mathrm{e}$ 항원과 $\mathrm{C}$ 항원이 동시에 양성인 혈구의 반 응도는 $4+$ 로 e항원만 양성인 혈구의 반응도인 $1+$ 혹은 $2+$ 에 비하여 강하였다. 따라서 항체 동정검사 시 양성/음성의 판 정뿐만 아니라 양성인 경우 반드시 반응 정도를 고려하여 강 한 경우에는 항원의 용량효과 이외에도 혼합항체 가능성을 반 드시 고려하여야 하며, 오답기관은 이에 대한 재교육이 필요할 것으로 여겨졌다. 또한 적혈구 혼합항체는 전체 동종면역환자 의 23.9\% (45/188)에서 발견되고 전체 동정된 항체의 $40.7 \%$ (100/246)를 차지하였다는 보고가 있듯이[7] 외부정도관리 물질로 혼합항체의 구성도 지속적으로 필요한 것으로 판단하 였다. 그러나 홈페이지의 결과 보고형식이 혼합항체인 경우에 는 정확한 정답률 산출이 곤란하여 별도 작업이 필요하므로 별도의 전산 수정작업이 필요한 것으로 판단하였다. 항체 선 별과 동정검사기법은 원주응집법이 1차(2차)가 각각 $90.46 \%$ (91.6\%)과 96.8\% (97.6\%)으로 2013년 87.6\% (87.3\%)과 $92.7 \%$ (95.0\%)에 비하여 점점 증가하는 양상을 보였다.

시범항목인 적혈구 $\mathrm{A} 1, \mathrm{H}$ 항원검사에 참여한 기관 수는 2012년도 62-67개 기관에서 2013년 58-60개, 2014년에는 53-49개로 더 감소하였다. 이는 2013년 보고서에서도[1] 지적 하였듯이 이들 시약, 특히 anti-H에 대하여 식약처 허가를 득 한 국내 업체가 없기 때문으로, 환자들의 안전을 위하여 이러 한 희귀 시약들에 대해서는 관련 업체들을 설득하고 또한 무조 건적으로 허가만을 강요하는 제도는 다시금 검토될 필요가 있 다고 여겨진다.

2014년에도 1회차 사업에 신규로 추가한 Rh subgrouping 검사에 참가한 기관도 45 기관이나 되며 판정을 잘못한 기관도 발견되어, 이 기관들에게 anti-C, anti-c, anti-E anti-e 시약
의 반응성을 검증하는 데 좋은 기회를 제공한 것으로 판단하였 다. 2014년 사업 시는 신규종목이라 반응 정도에 상관없이 양 성과 음성만을 기준으로 평가하였지만 향후에는 좀 더 정확한 평가를 위하여 새로운 기준을 적용할 필요가 있다고 여겨진다.

2014년 ABO 항체 역가검사의 정답률은 89.5-100.0\%로 2013년의 58.8-93.3\%에 비하여 높았는데, 이는 기관들의 검 사법이 향상될 수도 있으나 그것보다는 예년과는 달리 IgG가 주를 이루는 $\mathrm{O}$ 형이 아닌 $\mathrm{IgM}$ 이 주를 이루는 $\mathrm{A}$ 형 검체를 발송 하였기 때문인 것으로 분석하였다.

\section{REFERENCES}

1. Lim YA, Oh JS, Kwon SW, Kwon KC, Kim SY, Park KU, et al. Annual report on external quality assessment of blood bank tests in Korea (2013). J Lab Med Qual Assur 2014;36:55-63.

2. Lim YA, Oh JS, Kwon SW, Kwon KC, Kim SY, Park KU, et al. Annual report on external quality assessment in blood bank tests in Korea (2012). J Lab Med Qual Assur 2013;34(S1):S103-S15.

3. Lim YA, Oh JS, Kwon SW, Kwon KC, Kim SY, Park KU, et al. Annual report on external quality assessment in blood bank tests in Korea (2011). J Lab Med Qual Assur 2012;33(S1):S91-S104.

4. Lim YA, Oh JS, Kwon SW, Kwon KC, Kim SY, Park KU, et al. Annual report on external quality assessment in blood bank tests in Korea (2010). J Lab Med Qual Assur 2011;33(S1):S75-S89.

5. Kwon SW, Kim DW, Han KS, Kim HO, Seo JS, Cha YJ, et al. Annual report on external quality assessment in blood bank tests in Korea (2009). J Lab Med Qual Assur 2010;32:95-101.

6. Lim YA. Comprehensive analysis of the testing techniques used in blood bank laboratories in Korea for the past six years. J Lab Med Qual Assur 2014;36:23-9.

7. Kim JE, Kim BR, Woo KS, Han JY, Kim KH. The characteristics of concurrent blood group antibodies detected by unexpected antibody screening tests. Korean J Blood Transfus 2010;21:115-21. 
혈액은행분과 신빙도조사 결과보고(2014)

임영애 ${ }^{1}$ 오진숙 ${ }^{1}$ 권석운 ${ }^{2}$ 권계철 ${ }^{3}$ - 김신영 ${ }^{4}$ 박경운 ${ }^{5}$ - 박현준 ${ }^{2}$

송운흥 6 조 덕 $・$ 엄태현 ${ }^{8}$ - 이미경 ${ }^{9}$ 한상무 ${ }^{10}$ - 대한임상검사정도관리협회 혈액은행분과위원회

${ }^{1}$ 아주대학교 의과대학 진단검사의학과, ${ }^{2}$ 울산대학교 의과대학 서울아산병원 진단검사의학과, ${ }^{3}$ 충남대학교 의과대학 진단검사의학과, ${ }^{4}$ 연세대학교 의과대학 세브란스병원 진단검사의학과, ${ }^{5}$ 분당서울대병원 진단검 사의학과, ${ }^{6}$ 신한대학교 임상병리학과, ${ }^{7}$ 성균관대학교 의과대학 삼성서울병원 진단검사의학과, ${ }^{8}$ 인제대학교 일산백병원 진단검사의학과, ${ }^{9}$ 대한적십자사 중앙혈액검사센터, ${ }^{10}$ 대한적십자사 경기혈액원

2014년에 시행된 혈액은행검사에 대한 신빙도조사결과를 분석하였다. 검체는 아주대학교병원에서 직접 제조하였으며, 1차와 2차의 회신율은 각각 97.8\% (537/549)와 98.4\% (545/554)였다. 미

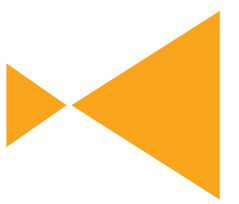

Journal of LABORATORY MEDICINE and

QUALITY ASSURANCE

입력은 오답으로 처리하였고, 정규 평가종목인 6 개 항목에 대한 평균 정답률은 다음과 같았다. $\mathrm{ABO}$ 혈액형검사 98.5-100.0\%, D 혈액형검사 98.1-99.4\%, 교차시험검사 91.2-99.6\%, 다특이성 직 접항글로불린검사 96.7-98.4\%, IgG 단특이성 직접항글로불린검사 93.8-98.7\%, C3d 단특이 성 직접항글로불린검사 89.5-98.7\%, 항체 선별검사 96.2-100.0\%, 그리고 항체 동정검사 69.8$100.0 \%$ 이었다. 시범항목으로는 anti-A1과 anti-H의 반응성, Rh subgrouping 그리고 ABO항체 역가검사를 시행하였다. 혼합항체가 포함된 검체에 대한 항체 동정검사의 결과를 제외하고는 2014 년도 혈액은행검사 신빙도결과는 전반적으로 우수하였으며 참여기관의 수는 2013년도에 비하여 더 확대되었다. 2014년도 혈액은행검사 신빙도사업은 참여한 검사실의 질을 향상시키는 데 도움을 준 것으로 여겨졌다.

(J Lab Med Qual Assur 2015;37:47-55)

교신저자: 임영애

우)443-380 경기도 수원시 영통구 월드컵로 164, 아주대학교 의과대학 진단검사의학과

Tel: 031)219-5786, Fax: 031)219-5778, E-mail: limyoung@ajou.ac.kr 